\title{
Guiding restoration of riparian ecosystems degraded by plant invasions: Insights from a complex social-ecological system in the Global South
}

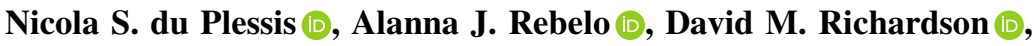 \\ Karen J. Esler (D)
}

Received: 3 June 2021/Revised: 27 August 2021/Accepted: 3 December 2021/Published online: 28 December 2021

\begin{abstract}
Restoring riparian ecosystems in human-dominated landscapes requires attention to complexity, and consideration of diverse drivers, social actors, and contexts. Addressing a Global North bias, this case study uses a mixed-method approach, integrating historical data, remote sensing techniques and stakeholder perceptions to guide restoration of a river in the Western Cape, South Africa. An analysis of aerial photographs of the riparian zone from 1953 to 2016 revealed that although anthropogenic land conversion happened primarily before the 1950s, several land use and land cover classes showed marked increases in area, including: waterbodies $(+1074 \%)$, urban areas $(+316 \%)$, alien weeds $(+311 \%)$ and terrestrial alien trees $(+79 \%)$. These changes have likely been driven by land fragmentation, disturbance, and agricultural intensification. Stakeholder interviews revealed that despite the clear need for restoration, several barriers exist to successful implementation; these stem from inadequate financial resources, inappropriate funding models, institutional challenges, and a lack of techno-scientific knowledge. We give several recommendations to overcome these barriers.
\end{abstract}

Keywords Biological invasions · Land use ·

Rehabilitation · Social-ecological systems .

Stakeholder perceptions . Tree invasions

Supplementary Information The online version contains supplementary material available at https://doi.org/10.1007/s13280021-01691-y.

\section{INTRODUCTION}

There is increasing recognition that nature-based solutions are needed to achieve biodiversity and climate goals in biodiverse countries in the Global South (Seddon et al. 2020). The IUCN defines nature-based solutions as "actions to protect, sustainably manage, and restore natural or modified ecosystems, whilst addressing societal challenges effectively and adaptively, simultaneously providing human well-being and biodiversity benefits" (CohenShacham et al. 2016). This is an umbrella term that embraces several ecosystem-based approaches, one of which is ecological restoration (JNCC 2021).

Despite the need for nature-based solutions in the Global South, most research in this field has been done in the Global North (de Souza and Torres 2021); there are few well developed studies that embrace Global South contexts (Du Toit et al. 2018). This is especially so for small cities and peri-urban areas, which are generally underrepresented in terms of nature-based solutions in the international literature (Chausson et al. 2020). To implement nature-based solutions across different contexts, the British Academy (Mabon 2021) acknowledges that case-study based research, specifically from the Global South, is urgently needed. We address this by presenting a nature-based solution case study to guide restoration of a river in the Western Cape of South Africa.

Rivers and riparian zones are often associated with human activity due to their water provisioning services (Richardson et al. 2007). As a result, these systems are degraded by human-mediated disturbances such as water abstraction, damming, land use changes, and recreational activities (Zelnik et al. 2020). Direct impacts of such disturbances facilitate invasion of alien plants, some of which out-compete and replace native species due to their ability 
to rapidly colonize disturbed areas and alter microclimates (Stella et al. 2012). Invasive alien trees in riparian zones significantly reduce streamflow and surface runoff (Richardson et al. 2007), alter water quality (Galatowitsch and Richardson 2005), cause loss of biodiversity (Sala et al. 2000), and diminish the capacity of these ecosystems to deliver key services (Guida-Johnson and Zuleta 2017).

Alien tree invasions severely threaten the biodiversity and integrity of riparian systems, with feedbacks to the economy and well-being of society (Dufour et al. 2011). In South Africa, degradation of ecosystem services results in direct economic losses, with the agricultural sector being impacted most heavily, followed by tourism, and water supply (Blignaut and Aronson 2020). Invasive plants currently reduce water yield by 38 million $\mathrm{m}^{3}$ per annum in the water-scarce Western Cape Province of South Africa (Le Maitre et al. 2019). To prevent further water losses, there has been substantial investment in the clearing of invasive stands as a nature-based solution. As the clearing of invasive species is often considered an action or intervention intended to promote the recovery of an ecosystem, it can be considered a restoration activity (SER 2004).

Ground surveys are the traditional method used to collect data for planning and monitoring restoration projects (Olorunfemi 1983). However, surveys do not allow reconstruction of historical changes in the landscape, whereas methods such as aerial photograph analysis, remote sensing and change detection may be used to analyse changes in land use and land cover (LULC) to inform land management decisions (Amini Parsa et al. 2016; Moulds et al. 2018). Although the strength of such analyses depends on the accuracy, cost, and resolution of the available imagery, such methods are useful when formulating guidelines for restoration, especially in developing countries where data are often scant or non-existent ( $\mathrm{Ai}$ et al. 2020). Although useful for identifying the rate, nature, and extent of LULC changes, geographic information system technologies are insufficient to explain underlying drivers and perceptions of these trends. Several studies have proposed assessing stakeholder perceptions as a complementary tool to better understand these dynamics (Munthali et al. 2019; Kariuki et al. 2021).

We employed an interdisciplinary, mixed-method approach using remote sensing, the collation of historical data, and stakeholder interviews to investigate the extent to which a degraded but ecologically important river in the Western Cape of South Africa should be restored. We aimed (i) to investigate the historical and social-cultural contexts of the landscape which influence stakeholder perceptions of invasive alien species (Potgieter et al. 2020); (ii) to understand the ecological and social drivers of invasions by mapping land use and land cover changes (Chaffin et al. 2016); (iii) to evaluate the social values, and perceptions of stakeholders associated with invasive alien species and their management through interviews (Curtin and Parker 2014); and (iv) to recommend sound planning strategies by identifying challenges and barriers (Dufour and Piégay 2009).

\section{THEORETICAL FRAMEWORK}

Because a key goal of many restoration projects is to improve the delivery of ecosystem services, efforts should be directed to meet social-ecological goals rather than focusing solely on ecological outcomes (Dufour et al. 2011; Abelson et al. 2015; Gann et al. 2019). Employing a social-ecological systems approach, which promotes a more integrated and holistic understanding of the interconnection between humans and nature, is therefore desirable for the restoration of degraded landscapes (Adams et al. 2020). Cooperation and collaboration between stakeholders and an understanding of the relationships between ecosystem functioning and ecosystem services is necessary to guide management.

The ecosystem services concept has increasingly been used as a tool in decision making and management (Alexander et al. 2016). However, conflicts can arise when restoration projects aim to target individual services rather than a full spectrum of ecosystem services (Bullock et al. 2011). This is often the case for invasive species management, as many invaders generate both benefits and costs to ecosystems and to society (Bullock et al. 2011; Potgieter et al. 2020). Analyzing ecosystem services bundles (sets of ecosystem services that appear together repeatedly across space or time) has been proposed as a tool for assessing common ecosystem service trade-offs and synergies in social-ecological systems (Karieva et al. 2007). The concept of ecosystem services bundles thus enables management to objectively evaluate ecosystem services; this helps to resolve conflicts of interest, contributing to the effective management of multi-functional landscapes (Le Maitre et al. 2011).

Ecological restoration is a nature-based solution that involves 'the process of assisting the recovery of damaged, degraded, or destroyed ecosystems to a reference condition' (SER 2004). However, total recovery of degraded ecosystems is difficult to achieve at large spatial scales due to factors such as threshold-level changes in ecosystems, limited resources, poor management, diverse and incompatible stakeholder aspirations for change, and a lack of stakeholder interest (Gaertner et al. 2012; Novoa et al. 2018; Shackleton et al. 2019; Adams et al. 2020). Rehabilitation is one of several activities along the restorative continuum and aims to reinstate a level of ecosystem functioning for ongoing provision of ecosystem services, 
where restoration to a reference ecosystem is not feasible in the short to medium term (Gann et al. 2019). Passive restoration and passive rehabilitation rely on spontaneous succession after degrading disturbances (such as alien plant species) are removed or reduced, whereas active measures involve planting of native species to facilitate recovery (Gann et al. 2019). In the long-term, rehabilitation may be a first step towards full-scale restoration (Alexander et al. 2016). However, for rivers in highly modified landscapes where total native ecosystem recovery is no longer possible, rehabilitation may be a more appropriate goal (Holmes et al. 2020).

In social-ecological systems where interactions between social and ecological components operate at multiple temporal and spatial scales, complexity arises due to interactions between factors such as land-tenure patterns, societal preferences, and policy. Such complexity complicates decision making, often emphasizing the gap between science and practice (Roura-Pascual et al. 2009; Reyers et al. 2015). This gap can be addressed by restoration-based education, a process whereby stakeholders possessing technical knowledge (e.g. researchers and specialists) are trained to run educational programs for local people to help them acquire knowledge about degraded ecosystems and to facilitate the recovery of these systems (Pérez et al. 2019; Garzón et al. 2020). Bringing multiple sectors, disciplines, and stakeholders together to 'co-produce' knowledge has been recommended as a solution to understand and adaptively manage social-ecological systems (Steger et al. 2020). Knowledge co-production is regarded as an iterative, transdisciplinary process that integrates diverse knowledge systems and capacities from various stakeholders (academic and non-academic) through a collaborative social learning process with the intention of generating innovative and legitimate knowledge to inform decision making (Angelstam et al. 2017; Djenontin and Meadow 2018).

\section{MATERIALS AND METHODS}

\section{Study area: the Dwars River}

The Dwars River valley (335' S; $\left.18^{\circ} 58^{\prime} \mathrm{E}\right)$ in the Western Cape, South Africa, is a drought-prone region (Fig. 1). A key water supply source for agricultural irrigation, the river and its banks are used by surrounding communities for recreational activities (i.e. swimming, picnicking, and walking). The landscape comprises a mixture of privately owned farms and three peri-urban settlements (Pniël, Kylemore, and Lanquedoc) characterized by complex landtenure patterns and governance. The combined population of the three settlements in the catchment is 10700 people, and the population density is $4049 / \mathrm{km}^{2}$ (Statistics South
Africa, 2011). The Dwars River valley has a Mediterranean climate with wet winters and warm or hot dry summers. Riparian zones within Mediterranean climate regions are highly susceptible to biological invasions due to common disturbance-driven resource fluctuations such as flooding and drought events, as well as nutrient pulses that create new habitats for alien species colonization (Galatowitsch and Richardson 2005; Stella et al. 2012).

The natural vegetation along the Dwars River riparian zone has largely been replaced by agricultural land and invasive plants, notably Alnus glutinosa (Black Alder), Acacia melanoxylon (Blackwood), Populus alba (White Poplar), Acacia dealbata (Silver Wattle), Acacia saligna (Port Jackson) and Acacia mearnsii (Black Wattle) (Belcher et al. 2015), (see Supplementary Material S1 for species list and S2 for photographs of invasions). The lower section of the river has the largest known invasive population of A. glutinosa in the Western Cape (Keet et al. 2020). The Biodiversity Spatial Plan Map indicates that the entire Dwars River valley has been designated an ecological support area, meaning that it plays a vital role in supporting the ecological functioning of Critical Biodiversity Areas (Pool-Stanvliet et al. 2017).

From August 2018 to the end of 2019, dense stands of invasive trees were cleared along the lower reaches of the Dwars River by a conservation trust with government funding. However, there are issues with the sustainability of this funding, impacting adequate follow-up maintenance, resulting in coppicing and re-invasion of species such as A. glutinosa and A. saligna (Keet et al. 2020).

\section{Historical context of the Dwars River valley}

Historical sources such as diary entries, landscape paintings, and maps aid in reconstructing landscapes prior to impacts such as plant invasion (Gann et al. 2019). A historical synopsis of the land was compiled using methodology similar to that applied by Van Rensburg et al. (2017). Firstly, information was obtained from personal communication with landowners. Although this information was mostly anecdotal, it advanced our understanding of how land use has changed over the last century. Secondly, historical records including old photographs, diary extracts, maps, and land surveys were accessed from the Pniel Museum. Thirdly, a book titled 'Beautiful Banhoek' (Hayden, 2015) provided a rich history of the Dwars River valley from the arrival of early settlers, slaves, and farmers to the present day.

\section{Land use and land cover change analysis}

Land use and land cover (LULC) surrounding the Dwars River over six decades was digitized using 1:30 000 aerial 

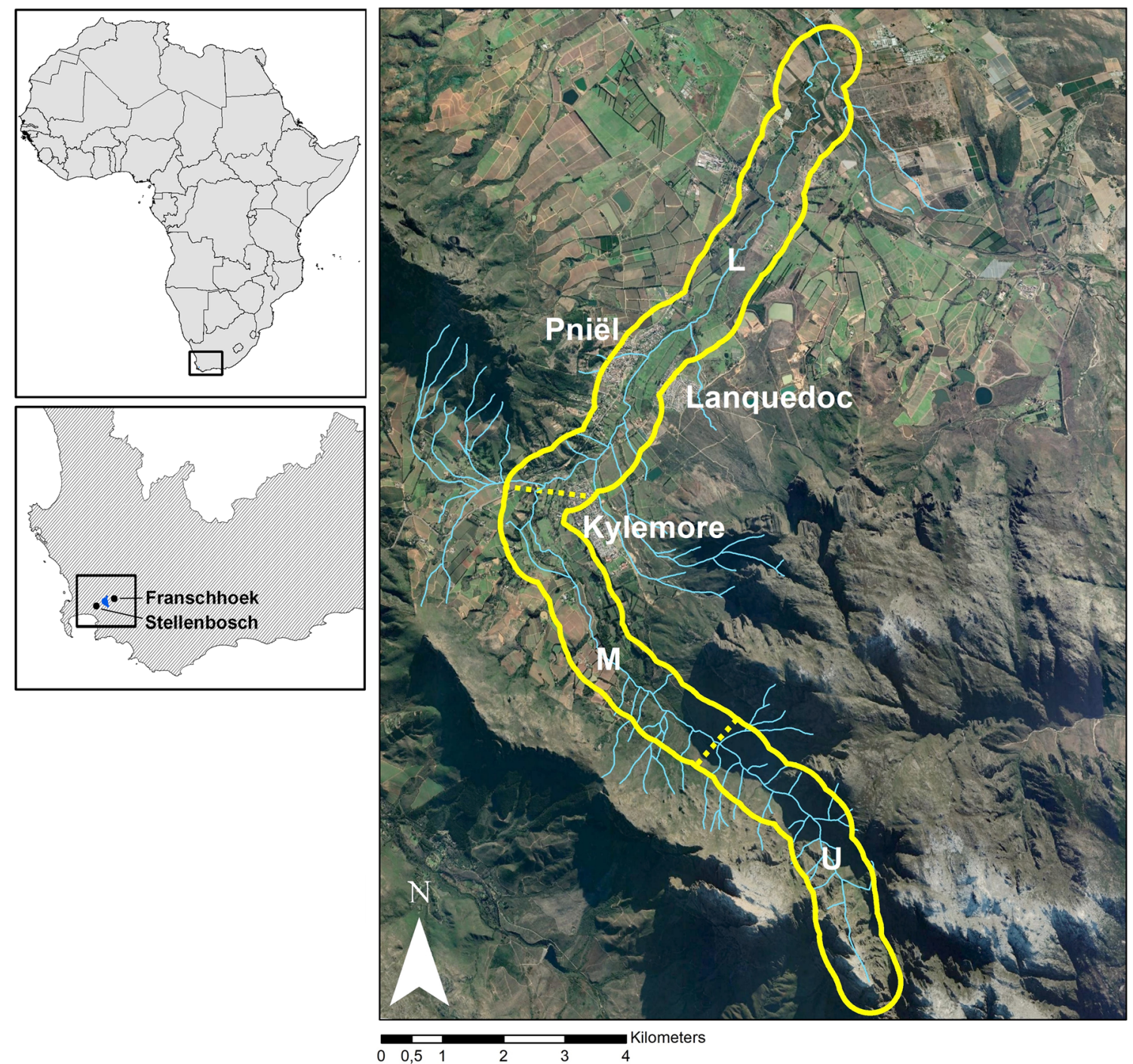

Fig. 1 The location of the Dwars River study area within the Western Cape of South Africa is shown in the two left hand side panels. The enlarged aerial photograph shows the study area (solid yellow line), which is the riparian zone, defined as a $250 \mathrm{~m}$ buffer on either side of the river. The study area is divided into three sections, namely $\mathrm{L}=$ lower section, $\mathrm{M}=$ middle section and $\mathrm{U}=$ upper section (dotted yellow lines demarcate each section) defined according to the two main watershed basins (image retrieved from Google Earth)

photographs from 1953 (the earliest available image), 1972, 1990 and 2016 (the most recent available image), using an approach described by Rebelo et al. (2017). Spatial resolution of the aerial photographs varied; 2016 had the highest resolution $(0.5$ by $0.5 \mathrm{~m})$ and 1953 had the lowest $(3.5 \mathrm{~m}$ by $3.5 \mathrm{~m})$. In South Africa, aerial photographs are superior to any other form of remote sensing for smaller areas due to their high temporal resolution (Rebelo et al. 2017). Imagery was acquired from the Chief Directorate: National Geo-spatial Information, South Africa. Images for 1972 and 1990 were selected as they were the only aerial photograph series taken of the entire study area over the period 1953-2016 with a relatively equal time gap. Imagery was georeferenced in ArcMap (v.10.4.1) using the most recent and highest resolution orthorectified photograph from 2016 as the reference image.

Fourteen LULC classes were digitized, including classes of invasive alien trees and weeds, agriculture, fallow land, bare soil, infrastructure, and native vegetation (Table 1). Crops currently farmed in the region are mainly grapes and deciduous fruit (citrus, plum, pear, peach, apple), while several farms grow proteas, maize, lucerne and vegetables. LULC was digitized for each of the four sets of aerial photographs.

It is often difficult to accurately classify LULC from scanned maps so a small degree of error can emerge during visual interpretation, whereby each land use and land cover category is identified and digitized (Jain et al. 2016). The accuracy of the output of the final LULC classes thus 
Table 1 Land use and land cover (LULC) classification scheme of the study area, defined by a $250 \mathrm{~m}$ buffer on either side of the Dwars River, Western Cape, South Africa

\begin{tabular}{ll}
\hline LULC class & Description \\
\hline Agriculture & Crop fields, planted pastures, and natural grazing lands \\
Bare soil & Land with exposed soil, sand or rocks \\
Fallow & Grassy patches with no obvious signs of current agricultural use \\
Native vegetation (riparian) & Native plants occurring naturally within the riparian zone \\
Native vegetation (terrestrial) & Native shrubland and forest patches mainly inhabiting rocky scree slopes \\
Alien trees (hardwood) & Trees planted for wood \\
Alien trees (terrestrial) & Trees $>$ 2 m that have invaded a terrestrial area \\
Alien trees (riparian) & Invasions of alien trees within the riparian zone \\
Alien trees (windbreak) & Alien trees planted in a single row around the edges of fields to shelter them from the wind and soil erosion \\
Alien weeds & Herbaceous plants $<2$ m that have invaded an area \\
Roads & Major highways, minor roads, dirt roads and hiking paths \\
Urban & Buildings and other man-made structures (e.g. school fields, tennis courts, recreational facilities, parking lots) \\
Waterbodies & Streams, rivers, dams, reservoirs \\
Wetlands & Areas of land that are saturated with water throughout the year, as well as non-perennial seeps \\
\hline
\end{tabular}

depends heavily on the interpreter. Herbaceous alien weeds $(<2 \mathrm{~m})$ and woody alien trees $(>2 \mathrm{~m})$ are relatively easy to distinguish from one another in aerial photographs due to their distinctive growth forms and textures. Whilst the growth of alien weeds was patchy with exposed groundcover between plants, woody alien trees were more uniform, with no bare ground showing between trees due to interlocking canopies. We could distinguish between alien and indigenous species based on our understanding of the ecology and habitat requirements of these species. The most difficult class to discriminate was that of wetlands, particularly in mountainous areas. However, as this study focusses mainly on the extent of invasive alien plants rather than wetlands, such error was not considered to be of great significance. Historical and anecdotal information confirmed that alien tree species have dominated the riparian zone for the last century.

Digitization of the most recent photograph (2016; hereafter the 'reference image') was supplemented by several data sources. Cape Farm Mapper (v.2.3.2.9) and Google Earth helped confirm features such as wetlands, windbreaks, roads, water basins and crop types. Data accessed from Google Earth Pro included historical aerial photographs (using the time slider tool), Google Street View and public photos stored in the database; while Cape Farm Mapper provided a crop census from 2017/2018, based on aerial photography from 2016 (Western Cape Department of Agriculture 2018), as well as a wetland dataset (Van Deventer et al. 2019). The distribution of alien tree species in the reference image was verified by a GIS dataset provided by Holden and Rebelo (2019). Drone footage of the Dwars River valley guided the interpretation of several classes of the reference image (Holden et al.
2021). Ground-truthing of various sites along the river verified the dominant invasive species. Historical imagery stored in Google Earth was also used as a supplementary source to cross-check imagery taken prior to the reference image.

Percentage cover assessments were conducted to establish the change in LULC classes over the four time intervals over the 63 years. This was done by summing area and perimeter data for the LULC classes for each year and comparing them between the four years. Relative change and absolute change in LULC classes were calculated. Invasion sources (hardwood blocks, windbreaks, urban areas) and possible dispersal routes (roads and rivers) were differentiated from invasion sinks (riparian and terrestrial infestations). To examine whether different parts of the riparian zone are undergoing changes in invasive alien tree cover at different rates, we divided the study area into three sections: (1) upper, (2) middle and (3) lower, according to the two main watershed basins within the study area (Fig. 1).

The Mann-Kendall test (Kendall 1948) was used to analyse data collected over time to determine monotonic trends. Using the trend package (Pohlert 2020) in RStudio, we compared the spread of the five classes of alien vegetation within the three river sections (lower, middle, upper) between 1953 and 2016 to establish where the spread of invasion was most significant and to determine which class of alien vegetation experienced the greatest changes in area. The Mann-Kendall test is useful for describing which trends are most powerful (Jain et al. 2016). The MannKendall ' $S$ ' statistic indicates whether monotonic trends are increasing (positive $\mathrm{S}$ ) or decreasing (negative $\mathrm{S}$ ). The 
greater the value, the more powerful the trend whilst a value of 0 suggests that there is no trend.

\section{Stakeholder interviews}

To understand public perceptions of invasive alien trees and ecological restoration, we conducted a set of semistructured interviews (of approximately $30 \mathrm{~min}$ duration) between September and October 2020. Using purposive and snowball sampling (Creswell and Creswell 2014), a total of 10 people who owned or managed properties bordering the Dwars River were selected (hereafter referred to as 'landowners'). Most interviews were conducted face-toface (adhering to strict Covid-19 protocols), but some were done telephonically. For the relatively small sample size, a broad range of landowners were interviewed, from small homeowners to landowners of large commercial farms, the aim being to capture a diverse range of perceptions (Table 2). To determine how much land within the study area was represented by the group of interviewees, we summed the area of each landowner's property occurring inside the study area, utilizing erf boundaries to delineate properties. We then calculated the overall percentage of land represented by the ten interviewees.

Interview questions were based on three broad topics that Gamborg et al. (2019) used in a similar process (see Supplementary S3 for interview questions). Topics included landowners' views on invasive alien species, their expectations of ecological restoration activities, as well as their willingness to be involved in future restoration efforts. The interview included several closed-ended questions in the form of Likert scales and Yes-No questions and a few open-ended questions. Interviews were recorded and transcribed, and data about the landowner and property were entered into a table (location, type and size of property, number of years spent on property) (Boyer et al. 2018). Due to the nature of the semi-structured interview schedule, both quantitative and qualitative analysis could be applied. Close-ended questions were quantitatively analysed by summing responses from each category and expressing these results as percentages, whilst open-ended questions were organized into themes for each question and quotes were extracted to provide context. Themes were developed inductively for each question to understand patterns in the data without any preexisting frame of reference, i.e. using phrases or terms used by the participants themselves (Richards and Hemphill 2018). This enabled us to offer credible interpretations and comparisons of the empirical material.

To deepen the understanding of our results, we conducted an unstructured interview with the project manager of a conservation trust active in the study area. Our aim was to develop a better understanding of the restoration strategy, as well as challenges and barriers faced by the implementer.

\section{RESULTS}

\section{Historical context of the Dwars River valley}

It was after 1687 when the Dutch Vryburger settlers were allocated land in the Dwars River valley that human activities began having a clear effect on the landscape (De

Table 2 General information about each interviewee's property and the number of years spent on the property

\begin{tabular}{|c|c|c|c|c|c|}
\hline & $\begin{array}{l}\text { Area of property (ha) } \\
\text { within study area }\end{array}$ & $\begin{array}{l}\text { Percentage of total } \\
\text { study extent }(\%)\end{array}$ & Type of property & $\begin{array}{l}\text { Section of river that } \\
\text { property borders }\end{array}$ & $\begin{array}{l}\text { Years on } \\
\text { property }\end{array}$ \\
\hline 1 & 7 & 0.34 & Household with a garden & Middle & 11 \\
\hline 2 & 217.88 & 10.49 & $\begin{array}{l}\text { Large-scale farm } \\
\text { (one type of crop) }\end{array}$ & Middle and upper & 24 \\
\hline 3 & 0.07 & 0 & Household with a garden & Lower & 29 \\
\hline 4 & 0.06 & 0 & Household with a garden & Lower & 8 \\
\hline 5 & 0.05 & 0 & Household with a garden & Lower & 9 \\
\hline 6 & 25 & 1.20 & $\begin{array}{l}\text { Small-scale farm } \\
\text { (many types of crops) }\end{array}$ & Lower & 19 \\
\hline 7 & 48.68 & 2.34 & $\begin{array}{l}\text { Large-scale farm } \\
\text { (one type of crop) }\end{array}$ & Middle & 13 \\
\hline 8 & 404.96 & 19.50 & $\begin{array}{l}\text { Large-scale farm } \\
\text { (many types of crops) }\end{array}$ & Lower & 4 \\
\hline 9 & 73.03 & 3.52 & Large game farm & Lower and middle & 10 \\
\hline 10 & 188.92 & 9.10 & $\begin{array}{l}\text { Large-scale farm } \\
\text { (many types of crops) }\end{array}$ & Middle and upper & 20 \\
\hline
\end{tabular}


Wet 1987). The Vryburgers were soon joined by the French Huguenots who had been exiled to the Cape. Together, the two groups divided the land into small parcels to keep cattle, sheep, and to plant grape vines (Coertzen et al. 1988). The first landowner of the Dwars River valley is said to have been Jean le Long, a Huguenot who was allotted the farm 'Bosendaal' (now Boschendal) in 1685.

An account of the farm was given in 1705 by Minister Francois Valentyn:

Here is one of the most noble estates that can be imagined... The house lies in a pretty and ornamentally laid out wood of lovely oaks (Hayden 2015, p. 4).

This quote confirms that oak trees (Quercus robur) were well established in the region in the early eighteenth century. This evidence is supported by Potgieter et al. (2020) who reported that oak trees were brought to the region by early European settlers as feature trees and for their use as timber products.

Although we could not find any evidence as to when and why invasive Australian Acacia species were brought to the valley, it is widely known that some species were brought to the Cape in the nineteenth century for tannin production and sand drift control, and several decades later, other species were brought for timber production (Le Maitre et al. 2011). According to Urgenson et al. (2013), landowners were incentivized by the State through 'tree growing competitions' to grow alien trees on their properties to render South Africa independent of international wood and timber markets. It is thus highly probable that Acacia species were brought to the Dwars River valley for similar reasons and spread to the riparian zone in subsequent years.

By 1960, several alien species were recognized as problematic, and widespread campaigns to remove invasive alien plants were initiated in the 1980s. The Conservation of Agricultural Resources Act (Act 43 of 1983) was proclaimed to regulate designated invasive alien plants on public and private land. Later, a more comprehensive piece of legislation was enacted, the National Environmental Management Biodiversity Act (Act 10 of 2004) which is in effect today.

\section{Land use and land cover change analysis}

There have been a few noticeable patterns in the overall extent of the LULC classes over the past 70-years (Fig. 2a; Supplementary Material S4). Within the riparian zone, native terrestrial vegetation and agricultural land covers the largest total area. Herbaceous alien weeds $(<2 \mathrm{~m}$ tall $)$ remained relatively constant across the first three time periods but increased markedly by 2016 . The opposite trend can be observed for hardwood blocks, the extent of which remained relatively unchanged until 1990 when there was a rapid decline.

In terms of relative change, the most significant increase in average area within the riparian zone between 1953 and 2016 was that of waterbodies (1074\%), mainly small farm dams (Fig. 2b). Several other significant increases were that of urban areas (316\%), as well as alien weeds (311\%), which both increased more than three times their initial extent in 1953. Alien terrestrial trees (79\%), wetlands $(65 \%)$, and roads $(53 \%)$ showed substantial expansion in average area between 1953 and 2016. Relative change calculations indicated several decreases in average area, with the greatest being that of alien hardwood blocks ($80 \%)$.

The total perimeter of all LULC classes increased most markedly within the riparian zone between 1990 and 2016, increasing from 752.37 to $1072.42 \mathrm{~km}$ (Fig. 3). Perimeter increased monotonically between the years for four LULC classes: alien terrestrial trees, roads, urban areas, and waterbodies, as a result of landscape fragmentation.

\section{Changes in land use and land cover between the lower, middle and upper sections of the riparian zone}

In the upper-middle section of the riparian zone there has been substantial infestation by invasive alien trees (Fig. 4). As there were few or no alien tree stands present in this area in 1953, this invasion must have occurred between 1953 and 1972. Alien weeds $(S=6, p=0.089)$ and alien terrestrial trees $(S=6, p=0.089)$ increased significantly in the middle section of the riparian zone of the Dwars River (see Supplementary Material S5).

\section{Stakeholder interviews}

The combined area of land owned or managed by the 10 landowners was calculated as $4339.18 \mathrm{ha}\left(43.39 \mathrm{~km}^{2}\right)$. Of this, the area of land that falls within our study area is $965.64 \mathrm{ha}\left(9.67 \mathrm{~km}^{2}\right)$ or $46 \%$ of the total study area. Landowner properties were all located adjacent to the river, with an almost equal representation from both the lower and middle sections of the river.

All participants expressed concern regarding the health of the river. Three landowners living adjacent to the lower section of the river mentioned the poorly functioning sewerage system built on the riverbanks: 


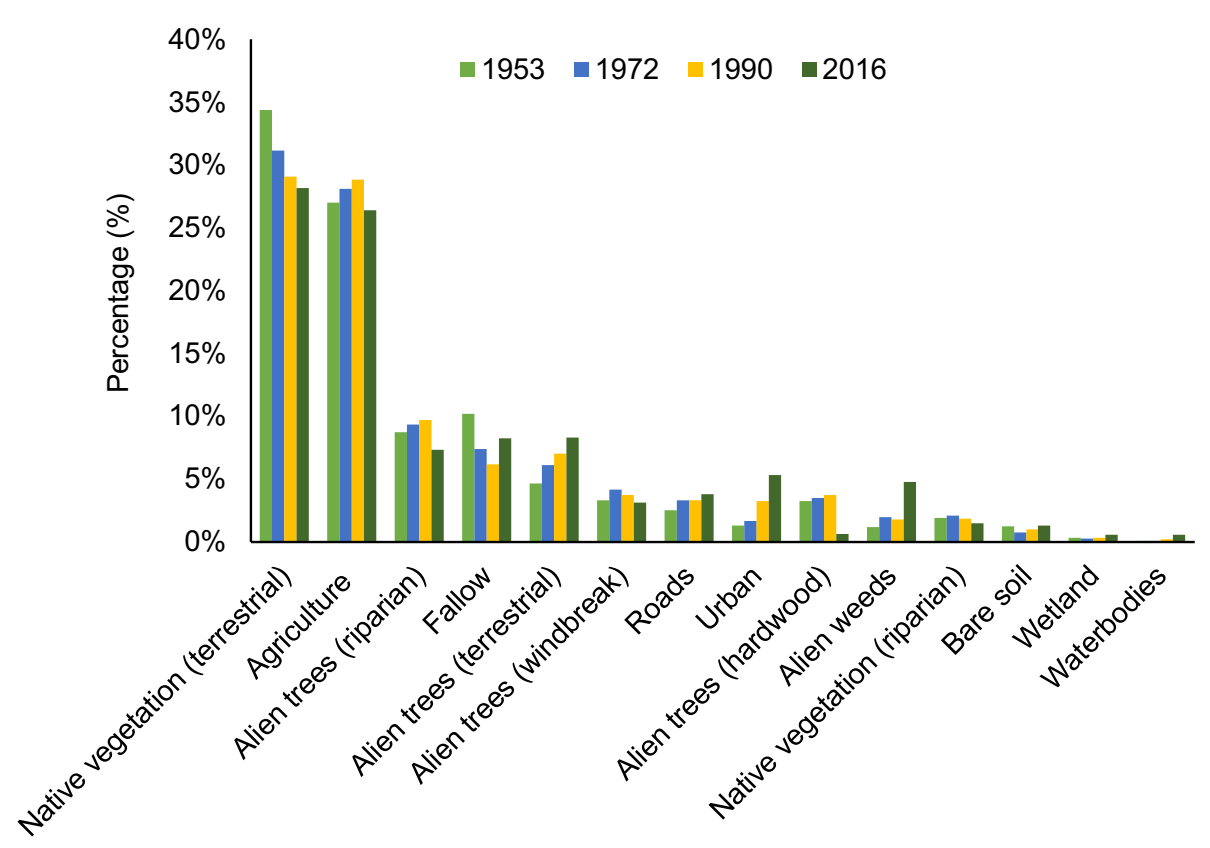

(a)

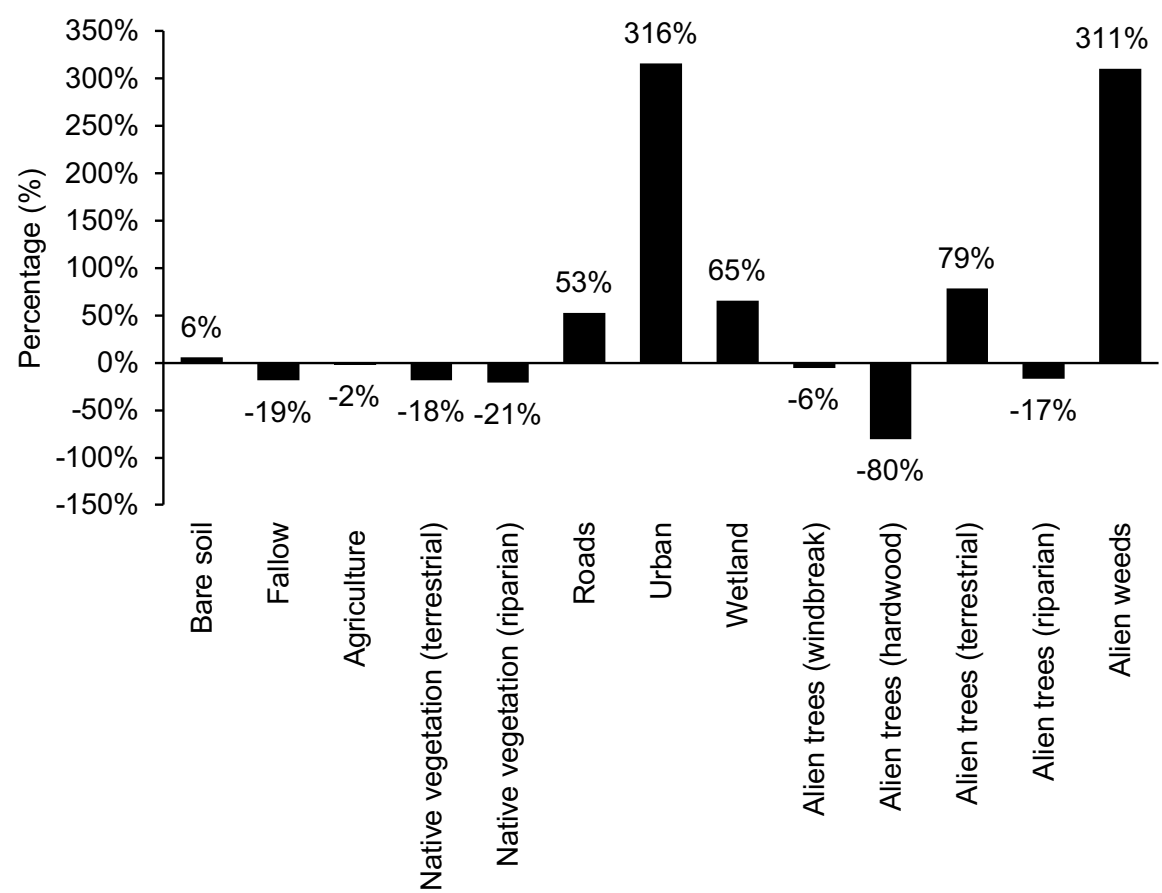

(b)

Fig. 2 a Percentage of the total study area that each land use and land cover class occupies for each of the four time intervals considered: 1953, 1972, 1990 and 2016 within the riparian zone. b Relative change in the area represented by each land use and land cover class between the earliest year that was mapped (1953) and the most recent year (2016) represented by (2016-1953/1953). To prevent distortion, waterbodies (value of $1074 \%$ ) have been removed 


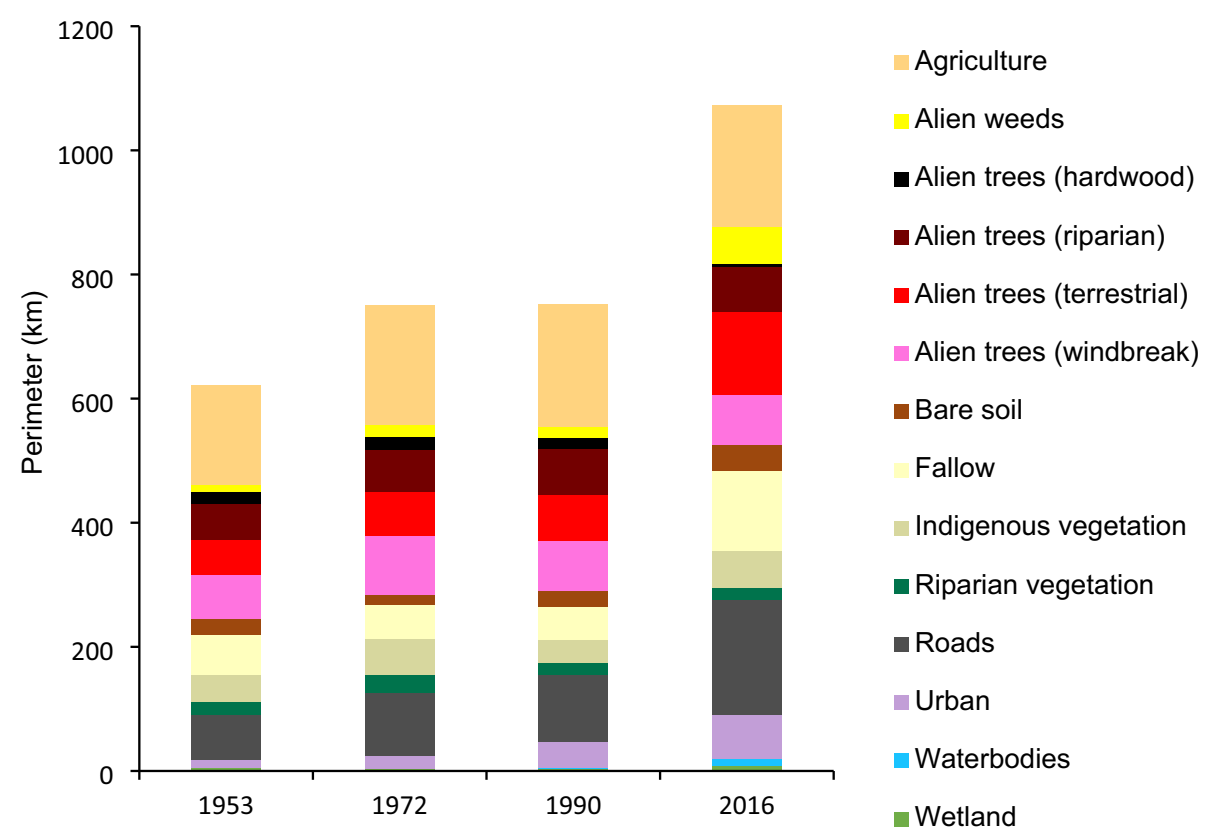

Fig. 3 Change in total perimeter $(\mathrm{km})$ of each land use and land cover class for the four time intervals mapped within the study area: 1953, 1972, 1990 and 2016

There is raw sewage that flows into the river through a pipe and it deteriorates the water quality. Most days you can smell the sewage. It is a health hazard to our kids who swim and play in the water.

In terms of water use, three of the largest farms have rights to abstract water from the river which they use for irrigation, and thus have a financial interest in keeping it clear of invasion.

All ten participants had prior knowledge of invasive tree species and provided examples. When asked if they thought all alien trees are detrimental to nature, participants had varying opinions. Overall, most people felt that not all alien trees are detrimental to nature. One landowner mentioned that he had planted Water Oak (Quercus nigra) trees along the riverbanks seven years ago, despite knowing they are alien species.

Although I know they are not indigenous, I do not want my Water Oaks removed. I think they are beautiful, and they stabilize the banks of the river. It would break my heart to see them go after seven years.

A similar opinion was held by two other landowners, who mentioned that they were upset when A. melanoxylon trees had been cut down on their properties by external contractors. As this tree species is listed as a category $1 \mathrm{~b}$ invasive species under the National Environmental Management Biodiversity (Act 10 of 2004), by law, landowners need to allow an authorized official to enter their land to control the prohibited species. In contrast, two other landowners had a slightly different argument. The first mentioned that after he had cleared Eucalyptus trees on the mountain within his property, he witnessed how the mountain spring continued to flow throughout the drought of 2018. The second felt that although alien trees may have short-term benefits - they should ultimately be removed as they have excessive water requirements. When asked if they are willing to contribute effort to restore the Dwars River, half of the participants acknowledged they could be doing more, whereas two believe they are already doing a lot. Those who believed they could do more involved suggested helping with physical labour and planting more native trees along the river. When asked whether ecological restoration should be prioritized along the Dwars River, most landowners agreed that it should. Supplementary Material S6 and S7 highlight the range of interviewee perspectives.

There was a discrepancy in responses as to who should be responsible for conducting and funding alien clearing activities along the Dwars River (Fig. 5). Only one person thought it should be an equal partnership between the land user and the government while the rest of the opinions were distributed relatively evenly between the other options. Several small-scale farmers shared the sentiment that they cannot afford to conduct regular alien clearing on their properties as it is expensive and time consuming, whilst one of the large-scale farm owners raised the point:

Even if I spend lots of money clearing my section, the effort is futile because if the landowner living $5 \mathrm{~km}$ 

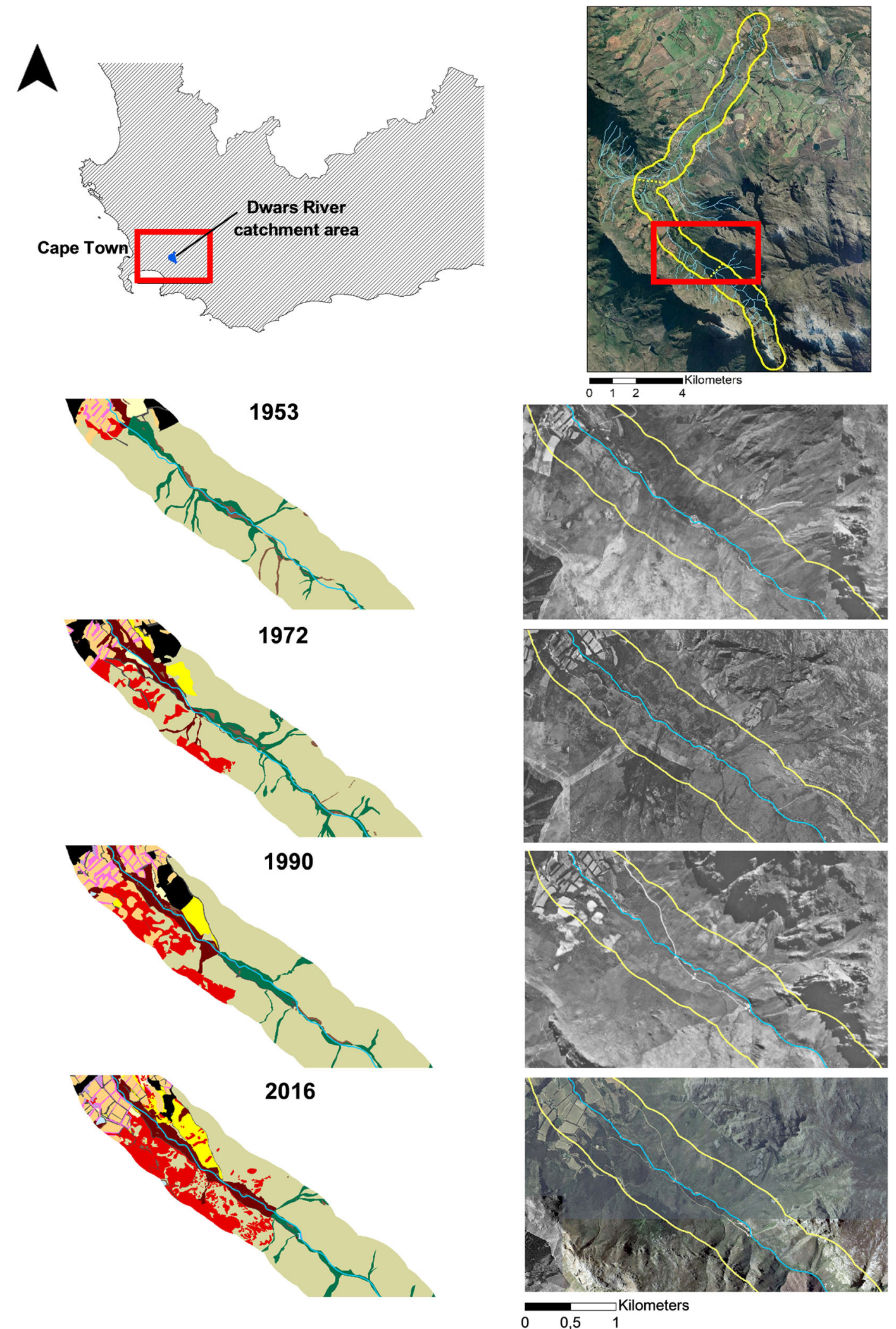

Fig. 4 Snapshots of the upper-middle reach of the Dwars River, in the Western Cape of South Africa, highlighting the rapid spread of invasive plants: Red-alien trees (terrestrial), Maroon—alien trees (riparian) and yellow-alien weeds from 1953 to 2016. Other important land-use and land cover changes include sandal—agriculture, blue—waterbodies, grey—native vegetation (riparian), rose-alien trees (windbreak) and black-alien trees (hardwood) (see Supplementary Material S4 for entire maps) 
upstream from me doesn't clear his section, his seeds will eventually end up on my property.

When asked why the conservation trust targeted dense invasions in the lower reaches of the river rather than sparse infestations in the upper reaches (the latter more likely to recover ecologically through spontaneous succession; Holmes et al. 2020), several barriers were listed including: financial constraints, an inappropriate funding model, a lack of engagement among stakeholders, a loss of institutional memory, and a lack of techno-scientific knowledge (Table 3). Additionally, this site was prioritized because the project manager wanted to tackle the 'biggest problem first' perceived to be the dense invasions of $A$. glutinosa occurring within this site (i.e. to reduce the source of propagules for the rest of the Berg River downstream). The team also wanted to work in an area with big visual impact for the community.

\section{DISCUSSION}

We first discuss the findings in two sections: (1) ecological reflections of alien clearing based on land-use/land-cover change analysis, and (2) social reflections on perceptions of, and challenges around alien clearing. We then merge

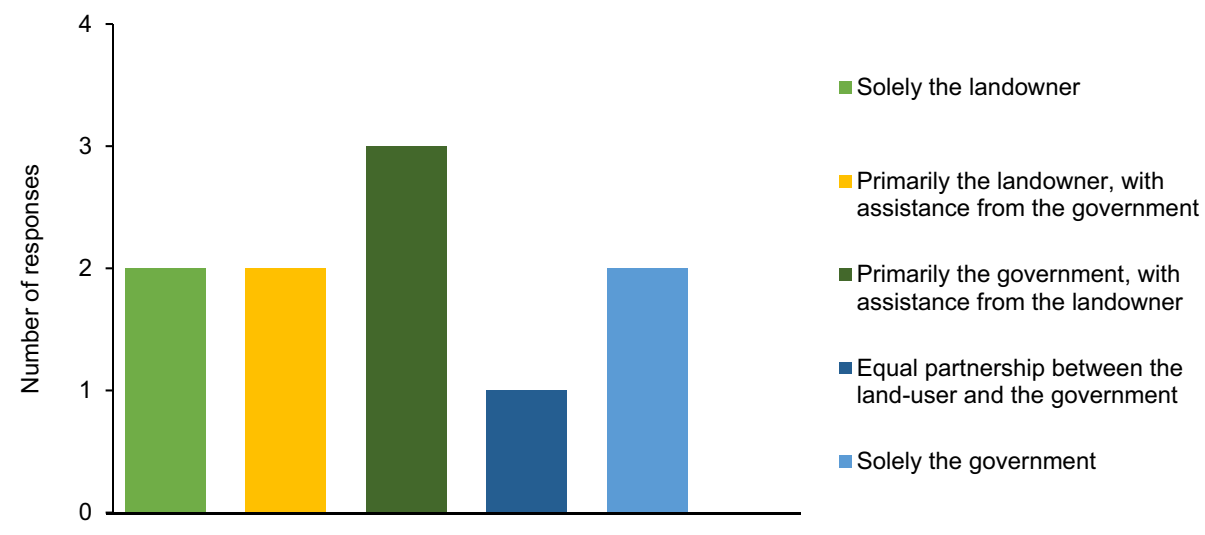

Fig. 5 Participants responses when asked who should be responsible for alien clearing activities along the Dwars River, Western Cape

Table 3 Barriers preventing successful implementation of previous alien clearing efforts along the riparian zone of the riparian zone of the Dwars River, Western Cape

Barriers to successful implementation of alien clearing strategies

Inadequate financial resources

Inappropriate funding model

Lack of engagement with private landowners

Loss of institutional memory

Lack of techno-scientific knowledge
Government funding allocated to alien clearing work was insufficient, posing barriers to working in an ecologically strategic way (e.g. targeting sites that were within walking distance of workers' homes to reduce transport costs)

The contract stipulated by the funding model was very short, making it impossible to create connections with a diverse group of stakeholders, and to interact with the funder for guidance (e.g. appropriate guidance on herbicide use). Additionally, only $22 \%$ of the budget could be allocated to stakeholder engagement, thus the amount of effort and time that could be invested in outreach and community engagement was severely constrained

Many private landowners were unwilling to support alien clearing activities as they are disconnected from the river, either because they live elsewhere or because they do not physically interact with it, or there is high ownership turnover. Additionally, some landowners were unwilling to have external workers on their properties due to cited safety reasons, or because invasive alien trees hide illegal activities like water abstraction. A platform to engage landowners did not exist

Communication with government was difficult due to a rapid turnover of staff working for the Municipality (time and effort was needed to build relationships within government, and when there was turnover of staff, the work had to be started again due to a lack of an adequate handover, or due to lack of interest from the new staff)

While the knowledge exists to work in ecologically strategic ways, these are not necessarily known or understood, especially by smaller contractors 
these reflections to make recommendations from a holistic socio-ecological systems perspective.

\section{Land-use/land-cover change as drivers of alien invasion of a riparian zone}

As land-use change has occurred in the Dwars River valley since the arrival of the European settlers over 300 years ago, there has been a long history of alien plant introductions into the area (Hayden 2015). In the last 60 years, agriculture has been the dominant land-use in the riparian zone, and the area devoted to this use has remained fairly constant. In contrast, urban areas have almost tripled in size over the last six decades. This trend is characteristic of peri-urban settlements, known to expand rapidly on the urban fringe (Živanović-Miljković et al. 2012). Possibly because of policy changes and agricultural intensification, combined with increasing need to improve water security under climate change, 12 new artificial farm dams were constructed on private land between 1953 and 2016. Intensive cultivation is recognized as a driver of invasion in that large numbers of alien propagules are intentionally introduced to landscapes through horticultural trade and unintentionally via transportation. Abstracting water from South African rivers for private use was made illegal by the National Water Act (Act 36 of 1998). Despite this, our interviews revealed that some farmers still illegally abstract water from the Dwars River as there is little or no enforcement of regulations. Our findings also suggest that the natural habitat of the valley has become more fragmented over time due to the increase in road networks, the increase in urban land, and farmland subdivision. Fragmented landscapes are more disturbed and are often heavily impacted by alien weeds which thrive in degraded sites (Nsikani et al. 2020). Increased fragmentation of land is thus also a driver of alien plant invasions. We consider the abovementioned land-use activities to be drivers of invasion as they alter hydrological flows and cause disturbance which facilitates the spread of invasive species (Richardson et al. 2007).

The noticeable decline in alien hardwood blocks within the riparian zone (likely harvested for wood products) between 1990 and 2016 has resulted in a significant increase in alien weeds in areas where these hardwood trees were cleared. This problem is commonly referred to as secondary invasion, defined as an increase in the abundance of non-target invasive species following treatment of targeted invasive plants (Pearson et al. 2016). Secondary invasion has been well documented in America, with case studies conducted in sand prairie grasslands (Symstad 2004), in coastal sage and perennial grassland communities on Santa Cruz Island, California (Erskine Ogden et al. 2005), and from the grasslands in western Montana (Ortega and Pearson 2010). In South Africa, few management interventions currently target secondary invasions (Nsikani et al. 2020). The extent of riparian vegetation dominated by alien trees remained relatively stable over the years, with a slight decline in the last 20 years. This recent decline is due to alien-plant clearing projects such as that initiated by the conservation trust along the lower reaches of the river. Despite some benefits acknowledged by the community (i.e. more aesthetic appeal after clearing), from an ecological perspective, these efforts are inefficient since several barriers prevent management from implementing the preferred ecological strategy; this highlights difficulties of working in complex socio-ecological systems (Liu and Cook 2015). Holmes et al. (2020) recommend that the most cost-effective way of clearing alien plant invasions is to target sites which have not yet crossed biological thresholds. This should be done in 'top-down' fashion (i.e. starting at the source of invasion and working downstream) as rivers are effective conduits of propagules (Le Maitre et al. 2019). Once abiotic or biotic thresholds are breached, native seed banks no longer persist, necessitating implementation of expensive active interventions (Gann et al. 2019). Thus, alien-plant clearing activities should be prioritized in sites with recent and/or low-density invasions to optimize spontaneous succession, such as sites in the upper-middle section of the Dwars catchment.

\section{Complexities arising from social-ecological systems}

Despite decades of sound ecological inputs and recommendations, and efforts to address the knowing-doing gap (Reyers et al. 2015), implementers are not following ecological restoration protocols. We explore major barriers to successful implementation of rehabilitation interventions from the perspective of implementers and landowners.

Barriers to successful implementation of restoration and rehabilitation projects are context specific. However, in certain contexts, particularly in less developed countries, barriers tend to overlap (e.g. Castán Broto et al. 2013). In our case study, although we only interviewed one manager, we gained insights about existing barriers preventing successful implementation of restoration activities along the Dwars River. In future, this manager will play an integral role in managing and controlling invasive alien species within the catchment, thus, her insights are of great value. First, budget and time constraints forced managers to neglect proper planning and stakeholder engagement. Insufficient funding has been acknowledged as a major constraint to the progress of ecological restoration in Europe (Tucker et al. 2013; Gantioler et al. 2014; Sewell et al. 2016; Rebelo et al. 2021). Implementing tax deduction measures for private investments in ecological restoration or a payment for ecosystem services scheme are two ways 
that could provide sustainable funding support in future (Cortina-Segarra et al. 2021). Second, managing and monitoring rehabilitation efforts along the Dwars River has proven difficult in recent years due to a loss of institutional memory with rapid turnover of staff and poor communication; this has led to confusion over who is responsible for managing invasive alien plants in the catchment. Adaptive collaborative governance, defined as 'the engagement of participants across boundaries of public agencies, levels of government and/or the public, private and civic spheres' (Emerson and Gerlak 2014) has been recommended as an approach to generate open and reliable communication and coordination systems between knowledge-producers and decision-makers to advance shared goals (Reyers et al. 2015). Third, there is apparent lack of stakeholder interest and knowledge of invasive species and their management. Limited techno-scientific knowledge is a challenge faced especially in developing countries where historical legacies of uneven development (e.g. colonialization and apartheid) yield different priorities and/or capacities to create or access knowledge (Gaertner et al. 2012; Shih et al. 2020). Angelstam et al. (2017) suggest that information, education, and communication are components of advocacy that persuade and mobilize people into action. If the science underpinning biological invasions and ecological rehabilitation is not well understood and supported by stakeholders, there is little chance that efforts to improve ecological functioning will succeed (Adams et al. 2020). All three of the barriers mentioned are common to developing country contexts (Shih et al. 2020).

The Dwars River valley comprises numerous land-parcels owned by a variety of stakeholders with diverse and sometimes conflicting perceptions and values of invasive alien species and their management (Dufour et al. 2011; Briske et al. 2017; Potgieter et al. 2020). Several landowners were opposed to the removal of certain alien tree species from their properties, and some even actively planted them, whereas others understood the implications of invasions and supported the need for management. Some alien tree species, notably A. melanoxylon (Australian Blackwood) were considered 'beautiful' trees that should be kept because they 'stabilize banks and prevent erosion'. This perception is incorrect from an ecological perspective, and it conflicts with policy. Legislation prohibits planting of these species in South Africa. In addition, Van Wilgen et al. (2020) showed how closed stands of alien trees reduce ground-layer vegetation thereby destabilizing soil leading to erosion of riverbanks. This increases the chance of flooding which puts human safety and property at risk. Thus, using the ecosystem-services concept (Bullock et al. 2011), the ecosystem disservices (soil erosion, biodiversity impacts, water regulation) ultimately outweigh the benefits (aesthetic services) to society. There is a need to address such misconceptions and trade-offs to prevent conflicts in future. This can be achieved through participatory workshops which are an effective communication platform for stakeholders to interact (Liu and Cook 2015). Understanding landowner interests and expectations and actively involving them in all stages of restoration via knowledge co-production is crucial to ensure mutually beneficial relationship between society and nature (Curtin and Parker 2014; Adams et al. 2020). However, if landowners are unwilling to comply with the law, necessary action must be taken.

While some wealthier landowners fund alien plant clearing on their properties, other landowners cannot afford the substantial investment required to clear dense stands of invasive alien trees and to maintain regular follow-up control. This is a sentiment shared by landowners in most developing countries. As government is unable to provide the resources needed to implement long-term rehabilitation and restoration projects, there is an urgent need to involve landowners in collective support of conservation efforts along degraded rivers in water-scarce areas (Urgenson et al. 2013; Meek et al. 2013). An effective way to coordinate and manage common water objectives while providing joint benefits is to connect a body of stakeholders that are representative of the diverse demographic within the catchment area. If concerned parties gather to address the issues, sustainable and long-term water security can be achieved through collective efforts and shared responsibility. This collaborative action, known as water stewardship, has been implemented globally. In Africa, successful water stewardship programmes have been established in Ethiopia, Kenya, South Africa, Tanzania, Uganda and Zambia (IwaSP 2019).

\section{Recommendations}

- Combining LULC change analysis with stakeholder interviews provides valuable insights for restoration planning. Mapping LULC sets the scene for the work by describing landscape context, reveals changes over time, and elucidates pressures the landscape faces. This sets the scene for restoration, allowing formulation of goals.

- The social-ecological systems approach complements this nature-based solution by engaging with people, understanding their views and roles in changing landscapes, and facilitating the refinement of realistic goals.

- Funding models should be revised and co-designed to allow for robust planning and adequate stakeholder engagement, and to increase flexibility (e.g. by combining stakeholder and government funds) to allow for 
implementation of appropriate management strategies (guided by science).

- Education of stakeholders through collaborative social learning processes should include consideration of a broader suite of ecosystem services important to the community (i.e. wildlife habitat, wood resources).

- Effective communication is needed to provide landowners with clear expectations regarding the level of invasive alien plant management and monitoring required over the long term.

- A stewardship programme should be initiated by implementers to unite a collective body of landowners in sharing the responsibility of rehabilitation the river.

\section{CONCLUSION}

This study contributes to the Global South literature on the multi-dimensional challenges of restoring degraded ecosystems. Such systems are inherently complex and present a diverse array of challenges to implementers. Challenges are compounded in developing countries by poor governance, limited resources, and a lack of education. In circumstances where resources are limited, contextspecific planning strategies should be devised before restoration projects commence.

The degradation of the Dwars River system has been caused by a long history of land use and land cover change that has altered hydrological regimes, caused physical changes to the river system, and facilitated invasions of alien plants. Restoring the entire riparian zone to its historical state is unrealistic (Meek et al. 2013). Instead, we provide several recommendations that will contribute to successful rehabilitation while considering stakeholder perceptions and values (e.g. improved communication between stakeholders, increased restoration-based education, revising existing funding models). Even when the goal is not to restore to a past ecosystem state, a holistic view is needed to understand landscape context and to inform appropriate goals along the restoration continuum in the face of new barriers and future opportunities. We acknowledge that this study has only considered alien tree clearing as one type of rehabilitation intervention and has not considered other measures such as geomorphological or hydrological rehabilitation (e.g. earthworks, and reinstating the ecological reserve). Management should be contextspecific to ensure the long-term success of future rehabilitation projects in South Africa and other developing countries.

Acknowledgements The authors acknowledge the interviewees for their cooperation and insightful opinions. We thank Lydia van Rooyen for her support and Charles Palm for conducting the interviews. This research has been ethically approved by the HSRC Research Ethics Committee (REC) (ethical clearance number: REC:SBE 13114) and was supported by the Centre for Invasion Biology and the South African Water Research Commission (WRC) through a Water JPI funded project, NATWIP (Nature-based solutions for water management in the peri-urban: linking ecological, social and economic dimensions, C2019/2020-00034). The WRC project reference group and manager, $\mathrm{Mr}$ Bonani Madikizela, are thanked for their inputs.

\section{REFERENCES}

Abelson, A., B. Halpern, D. Reed, R. Orth, G. Kendrick, M. Beck, J. Belmaker, G. Krause, et al. 2015. Upgrading marine ecosystem restoration using ecological social concepts. BioScience 66: $156-163$.

Adams, J., A. Whitfield, and L. Van Niekerk. 2020. A socioecological systems approach towards future research for the restoration, conservation and management of southern African estuaries. African Journal of Aquatic Science 45: 231-241.

Ai, J., C. Zhang, L. Chen, and D. Li. 2020. Mapping annual land use and land cover changes in the Yangtze Estuary region using an object-based classification framework and Landsat time series data. Sustainability 12: 659.

Alexander, S., J. Aronson, O. Whaley, and D. Lamb. 2016. The relationship between ecological restoration and the ecosystem services concept. Ecology and Society 21: 34.

Amini Parsa, V., A. Yavari, and A. Nejadi. 2016. Spatio-temporal analysis of land use/land cover pattern changes in Arasbaran Biosphere Reserve: Iran. Modeling Earth Systems and Environment 2: 1-13.

Angelstam, P., G. Barnes, M. Elbakidze, C. Marais, A. Marsh, S. Polonsky, D.M. Richardson, N. Rivers, et al. 2017. Collaborative learning to unlock investments for functional ecological infrastructure: Bridging barriers in social-ecological systems in South Africa. Ecosystem Services 27: 291-304.

Belcher, T., D. Grobler, and S. Barrow. 2015. Freshwater assessment for the proposed Boschendal hydroelectric scheme. Somerset West: Blue Science.

Blignaut, J., and J. Aronson. 2020. Developing a restoration narrative: A pathway towards system-wide healing and a restorative culture. Ecological Economics 168: 106483.

Boyer, A., E. Comby, S. Flaminio, Y. Le Lay, and M. Cottet. 2018. The social dimensions of a river's environmental quality assessment. Ambio 48: 409-422. https://doi.org/10.1007/ s13280-018-1089-9.

Briske, D.D., A.W. Illius, and J.M. Anderies. 2017. Nonequilibrium ecology and resilience theory. In Rangeland systems, ed. D.D. Briske, 197-227. Cham: Springer.

Bullock, J.M., J. Aronson, A.C. Newton, R.F. Pywell, and J.M. ReyBenayas. 2011. Restoration of ecosystem services and biodiversity: Conflicts and opportunities. Trends in Ecology \& Evolution 26: $541-549$.

Castán Broto, V., B. Oballa, and P. Junior. 2013. Governing climate change for a just city: Challenges and lessons from Maputo, Mozambique. Local Environment 18: 678-704.

CDNGI Geospatial Portal. 2020. Cdngiportal.co.za. Retrieved June 23, 2021 from http://www.cdngiportal.co.za/cdngiportal/.

Chaffin, B., A. Garmestani, D. Angeler, D. Herrmann, C. Stow, M. Nyström, J. Sendzimir, M. Hopton, et al. 2016. Biological invasions, ecological resilience and adaptive governance. Journal of Environmental Management 183: 399-407.

Chausson, A., B. Turner, D. Seddon, N. Chabaneix, C.A. Girardin, V. Kapos, I. Key, D. Roe, A. Smith, S. Woroniecki, and N. Seddon. 
2020. Mapping the effectiveness of nature-based solutions for climate change adaptation. Global Change Biology 26: 6134-6155.

Coertzen, P., F. Fensham, and P. Grobbelaar. 1988. The Huguenots of South Africa 1699-1988. Franschhoek: Huguenot Society of South Africa.

Cohen-Shacham, E., G. Walters, C. Janzen, and S. Maginnis. 2016. Nature-based solutions to address global societal challenges. Gland, Switzerland, IUCN 97.

Cortina-Segarra, J., I. García-Sánchez, M. Grace, P. Andrés, S. Baker, C. Bullock, K. Decleer, L. Dicks, et al. 2021. Barriers to ecological restoration in Europe: expert perspectives. Restoration Ecology. https://doi.org/10.1111/rec.13346.

Creswell, J., and J. Creswell. 2014. Research design, 4th ed. California: SAGE.

Curtin, C., and J. Parker. 2014. Foundations of resilience thinking. Conservation Biology 28: 912-923.

de Souza, D., and P. Torres. 2021. Greening and just cities: Elements for fostering a South-North dialogue based on a systematic literature review. Frontiers in Sustainable Cities. https://doi.org/ $10.3389 /$ frsc. 2021.669944.

De Wet, G. 1987. White settlement in the Drakenstein Valley up to 1700. In Paarl Valley, ed. A. Oberholster, 1687-1987. Pretoria: Human Sciences Research Council.

du Toit, M., S. Cilliers, M. Dallimer, M. Goddard, S. Guenat, and S. Cornelius. 2018. Urban green infrastructure and ecosystem services in sub-Saharan Africa. Landscape and Urban Planning 180: 249-261.

DeJonckheere, M., and L.M. Vaughn. 2019. Semi-structured interviewing in primary care research: a balance of relationship and rigour. Family Medicine and Community Health 7: e000057.

Djenontin, I., and A. Meadow. 2018. The art of co-production of knowledge in environmental sciences and management: Lessons from international practice. Environmental Management 61: 885-903.

Dufour, S., A. Rollet, J. Oszwald, and X. de Sartre. 2011. Ecosystem services, an opportunity to improve restoration practices in river corridors. Unpublished research note (02/2012). https://hal. archives-ouvertes.fr/hal-00587959/document.

Dufour, S., and H. Piégay. 2009. From the myth of a lost paradise to targeted river restoration: Forget natural references and focus on human benefits. River Research and Applications 25: 568-581.

Emerson, K., and A. Gerlak. 2014. Adaptation in collaborative governance regimes. Environmental Management 54: 768-781.

Erskine Ogden, J., and M. Rejmánek. 2005. Recovery of native plant communities after the control of a dominant invasive plant species, Foeniculum vulgare: Implications for management. Biological Conservation 125: 427-439.

Gaertner, M., P.M. Holmes, and D.M. Richardson. 2012. Biological invasions, resilience and restoration. In Restoration ecology The new frontier, ed. J. van Andel and J. Aronson, 265-280. Oxford: Wiley-Blackwell.

Galatowitsch, S.M., and D.M. Richardson. 2005. Riparian scrub recovery after clearing of invasive alien trees in headwater streams of the Western Cape, South Africa. Biological Conservation 122: 509-521.

Gamborg, C., J. Morsing, and K. Raulund-Rasmussen. 2019. Adjustive ecological restoration through stakeholder involvement: A case of riparian landscape restoration on privately owned land with public access. Restoration Ecology 27: 1073-1083.

Gann, G.D., T. McDonald, B. Walder, J. Aronson, C.R. Nelson, J. Jonson, J. Hallett, C. Eisenberg, et al. 2019. International principles and standards for the practice of ecological restoration. Restoration Ecology 27: S1-S46.

Gantioler, S., M. Rayment, P. Brink, A. McConville, M. Kettunen, and S. Bassi. 2014. The costs and socio-economic benefits associated with the Natura 2000 network. International Journal of Sustainable Society 6: 135.

Garzón, N., C. Rodríguez León, E. Ceccon, and D. Pérez. 2020. Ecological restoration-based education in the Colombian Amazon: Toward a new society-nature relationship. Restoration Ecology 28: 1053-1060.

Guida-Johnson, B., and G. Zuleta. 2017. Riparian rehabilitation planning in an urban-rural gradient: Integrating social needs and ecological conditions. Ambio 46: 578-587.

Hayden, S. 2015. Beautiful Banhoek. Stellenbosch: Keith Phillips Publishing.

Holden, P.B., A.J. Rebelo, and M. New. 2021. Mapping invasive alien trees in water towers: a combined approach using satellite data fusion, drone technology and expert engagement. Remote Sensing Applications Society and Environment 21: 100448.

Holden, P.B., and A.J. Rebelo. 2019. Mapping invasive alien trees in strategic water source areas in the Berg and Breede catchments. Preprint at arXiv 1902: 08035.

Holmes, P.M., D.M. Richardson, K.J. Esler, E.T.F. Witkowski, and S. Fourie. 2005. A decision-making framework for restoring riparian zones degraded by invasive alien plants in South Africa. South African Journal of Science 101: 553-565.

Holmes, P.M., K.J. Esler, B.W. van Wilgen, and D.M. Richardson. 2020. Ecological restoration of ecosystems degraded by invasive alien plants in South African fynbos: Is spontaneous succession a viable strategy? Transactions of the Royal Society of South Africa 75: 111-139.

International Water Stewardship Programme (IWaSP). 2019. International Water Stewardship Programme Annual Report 2018/2019. Eschborn: International Water Stewardship Programme.

Jain, M., D. Dawa, R. Mehta, A.P. Dimri, and M.K. Pandit. 2016. Monitoring land use change and its drivers in Delhi, India using multi-temporal satellite data. Modeling Earth Systems and Environment 2: 19-33.

JNCC. 2021. Nature-based Solutions Triple Win Toolkit - International Climate Finance Evidence Project. Peterborough: JNCC.

Kareiva, P., S. Watts, R. McDonald, and T. Boucher. 2007. Domesticated nature: Shaping landscapes and ecosystems for human welfare. Science 316: 1866-1869.

Kariuki, R., L. Munishi, C. Courtney-Mustaphi, C. Capitani, A. Shoemaker, P. Lane, and R. Marchant. 2021. Integrating stakeholders' perspectives and spatial modelling to develop scenarios of future land use and land cover change in northern Tanzania. PLoS ONE 16: e0245516.

Keet, J.H., M.P. Robertson, and D.M. Richardson. 2020. Alnus glutinosa (Betulaceae) in South Africa: Invasive potential and management options. South African Journal of Botany 135: 280-293.

Kendall, M. 1948. Sequential analysis. Nature 157: 642.

Le Maitre, D., A. Görgens, G. Howard, and N. Walker. 2019. Impacts of alien plant invasions on water resources and yields from the Western Cape Water Supply System (WCWSS). Water SA 45: 568-579.

Le Maitre, D., M. Gaertner, E. Marchante, E. Ens, P. Holmes, A. Pauchard, P. O'Farrell, A. Rogers, et al. 2011. Impacts of invasive Australian acacias: Implications for management and restoration. Diversity and Distributions 17: 1015-1029.

Liu, S., and D. Cook. 2015. Eradicate, contain, or live with it? Collaborating with stakeholders to evaluate responses to invasive species. Food Security 8: 49-59.

Mabon, L. 2021. Nature-based solutions and the green economy. London: The British Academy.

McCormick, F., G. Contreras, and S. Johnson. 2010. A dynamic invasive species research vision: opportunities and priorities 2009-29. In Effects of nonindigenous invasive species on water 
quality and quantity, ed. M. Dix and K. Britton, 111-120. Washington, DC: Department of Agriculture, Forest Service, Research and Development Washington.

Meek, C.S., D.M. Richardson, and L. Mucina. 2013. Plant communities along the Eerste River, Western Cape, South Africa: Community descriptions and implications for restoration. Koedoe 55: 1-14.

Metzger, J., K. Esler, C. Krug, M. Arias, L. Tambosi, R. Crouzeilles, A. Acosta, P. Brancalion, et al. 2017. Best practice for the use of scenarios for restoration planning. Current Opinion in Environmental Sustainability 29: 14-25.

Moulds, S., W. Buytaert, and A. Mijic. 2018. A spatio-temporal land use and land cover reconstruction for India from 1960-2010. Scientific Data 5: 180159.

Munthali, M., N. Davis, A. Adeola, J. Botai, J. Kamwi, H. Chisale, and O. Orimoogunje. 2019. Local perception of drivers of landuse and land-cover change dynamics across Dedza District Central Malawi Region. Sustainability 11: 832.

Novoa, A., R. Shackleton, S. Canavan, C. Cybèle, S. Davies, K. Dehnen-Schmutz, J. Fried, M. Gaertner, et al. 2018. A framework for engaging stakeholders on the management of alien species. Journal of Environmental Management 205: 286-297.

Nsikani, M., S. Geerts, S. Ruwanza, and D.M. Richardson. 2020. Secondary invasion and weedy native species dominance after clearing invasive alien plants in South Africa: Status quo and prognosis. South African Journal of Botany 132: 338-345.

Olorunfemi, J. 1983. Monitoring urban land use in developing countries-An aerial photographic approach. Environment International 9: 27-32.

Ortega, Y., and D. Pearson. 2011. Long-Term Effects of weed control with Picloram along a gradient of Spotted Knapweed Invasion. Rangeland Ecology and Management 64: 67-77.

Pearson, D., Y. Ortega, J. Runyon, and J. Butler. 2016. Secondary invasion: The bane of weed management. Biological Conservation 197: 8-17.

Pérez, D., F. González, M. Araujo, D. Paredes, and E. Meinardi. 2019. Restoration of society-nature relationship based on education: A model and progress in Patagonian drylands. Ecological Restoration 37: 182-191.

Pieterse, P., and A. Cairns. 1986. The effect of fire on an Acacia longifolia seed bank in the south-western Cape. South African Journal of Botany 52: 233-236.

Pohlert, T. 2020. Non-parametric trend tests and change-point detection. $R$ Package Version 1: 4.

Pool-Stanvliet, R., A. Duffell-Canham, R. Smart, and R. 2017. The Western Cape biodiversity spatial plan handbook. Stellenbosch: CapeNature.

Potgieter, L., E. Douwes, M. Gaertner, J. Measey, T. Paap, and D.M. Richardson. 2020. Biological invasions in South Africa's urban ecosystems: patterns, processes, impacts, and management. In Biological invasions in South Africa, ed. B.W. Van Wilgen, J. Measey, D.M. Richardson, J.R. Wilson, and T.A. Zengeya, 291-313. Berlin: Springer.

Rebelo, A.J., P. Scheunders, K.J. Esler, and P. Meire. 2017. Detecting, mapping and classifying wetland fragments at a landscape scale. Remote Sensing Applications: Society and Environment 8: 212-223.

Rebelo, A.J., P.B. Holden, K.J. Esler, and M.G. New. 2021. Benefits of water-related ecological infrastructure investments to support sustainable land-use: a review of evidence from critically waterstressed catchments in South Africa. Royal Society Open Science. 8: 201402.

Reyers, B., J. Nel, P. O'Farrell, N. Sitas, and D. Nel. 2015. Navigating complexity through knowledge coproduction: Mainstreaming ecosystem services into disaster risk reduction. Proceedings of the National Academy of Sciences 112: 7362-7368.
Richards, K., and M. Hemphill. 2018. A practical guide to collaborative qualitative data analysis. Journal of Teaching in Physical Education 37: 225-231.

Richardson, D.M., P.M. Holmes, K.J. Esler, S.M. Galatowitsch, J. Stromberg, S. Kirkman, P. Pyšek, and R. Hobbs. 2007. Riparian vegetation: Degradation, alien plant invasions, and restoration prospects. Diversity and Distributions 13: 126-139.

Roura-Pascual, N., D.M. Richardson, R.M. Krug, A. Brown, R.A. Chapman, G.G. Forsyth, D.C. Le Maitre, M.P. Robertson, L. Stafford, B.W. van Wilgen, A. Wannenburgh, and N. Wessels. 2009. Ecology and management of alien plant invasions in South African fynbos: Accommodating key complexities in objective decision making. Biological Conservation 142: 1595-1604.

Sala, O.E., F.S. Chapin, J.J. Armesto, E. Berlow, J. Bloomfield, R. Dirzo, E. Huber-Sanwald, L.F. Huenneke, et al. 2000. Global biodiversity scenarios for the year 2100. Science 287: 1770-1774.

Seddon, N., E. Daniels, R. Davis, A. Chausson, R. Harris, X. HouJones, S. Huq, V. Kapos, et al. 2020. Global recognition of the importance of nature-based solutions to the impacts of climate change. Global Sustainability. https://doi.org/10.20944/ preprints201810.0203.v2.

Sewell, A., J. Bouma, and S. van der Esch. 2016. Investigating the challenges and opportunities for scaling up ecosystem restoration. The Hague: PBL Netherlands Environmental Assessment Agency.

Shackleton, R.T., T. Adriaens, G. Brundu, K. Dehnen-Schmutz, R. Estévez, B.M.H. Larson, S. Liu, E. Marchante, H. Marchante, C. Moshobane, A. Novoa, and D.M. Richardson. 2019. Stakeholder engagement in the study and management of invasive alien species. Journal of Environmental Management 229: 88-101.

Shih, W., L. Mabon, and J. Puppim de Oliveira. 2020. Assessing governance challenges of local biodiversity and ecosystem services: barriers identified by the expert community. Land Use Policy 91: 104291.

Society for Ecological Restoration (SER). 2004. The SER international primer on ecological restoration. Society for Ecological Restoration International: www.ser.org and Tucson.

Statistics South Africa. 2011. Census 2011 Statistical release. P0301.4/Statistics South Africa. Pretoria: Statistics South Africa.

Steger, C., G. Nigussie, M. Alonzo, B. Warkineh, J. Van Den Hoek, M. Fekadu, P. Evangelista, and J. Klein. 2020. Knowledge coproduction improves understanding of environmental change in the Ethiopian highlands. Ecology and Society 25: 2.

Stella, J., P. Rodríguez-González, S. Dufour, and J. Bendix. 2012. Riparian vegetation research in Mediterranean-climate regions: Common patterns, ecological processes, and considerations for management. Hydrobiologia 719: 291-315.

Symstad, A. 2004. Secondary invasion following the reduction of Coronilla varia (Crownvetch) in Sand Prairie. The American Midland Naturalist 152: 183-189.

Tucker, G., E. Underwood, A. Farmer, R. Scalera, I. Dickie, A. McConville, and W. van Vliet. 2013. Estimation of the financing needs to implement target 2 of the EU biodiversity strategy. Report to the European Commission. London: Institute for European Environmental Policy.

Urgenson, L., H. Prozesky, and K. Esler. 2013. Stakeholder perceptions of an ecosystem services approach to clearing invasive alien plants on private land. Ecology and Society 18: 26.

Van Deventer, H., L. Smith-Adao, N. Mbona, C. Petersen, A. Skowno, N. Collins, M. Grenfell, and N. Job et al. 2019. South African National Biodiversity Assessment 2018: technical report. Pretoria: Council for Scientific and Industrial Research (CSIR) and South African National Biodiversity Institute (SANBI).

Van Rensburg, J., B.W. van Wilgen, and D.M. Richardson. 2017. The challenges of managing invasive alien plants on private land in 
the Cape Floristic Region: Insights from Vergelegen Wine Estate (2004-2015). Transactions of the Royal Society of South Africa 72: 207-216.

Van Wilgen, B.W. 2015. Plantation forestry and invasive pines in the Cape Floristic Region: Towards conflict resolution. South African Journal of Science 111: 1.

Van Wilgen, B.W., J.R. Wilson, A. Wannenburgh, and L.C. Foxcroft. 2020. The Extent and Effectiveness of Alien Plant Control Projects in South Africa. In Biological invasions in South Africa, ed. B.W. van Wilgen, J. Measey, D.M. Richardson, J.R. Wilson, and T.A. Zengeya, 597-628. Cham: Springer.

Vaz, A., C. Kueffer, C. Kull, D.M. Richardson, S. Schindler, A. Muñoz-Pajares, J. Vicente, J. Martins, et al. 2017. The progress of interdisciplinarity in invasion science. Ambio 46: 428-442.

Western Cape Department of Agriculture. 2018. Research and Technology Development Services | Agriculture. Retrieved June 29, 2018 from https://www.elsenburg.com/services-andprogrammes/research-and-technology-development-services.

Zelnik, I., V. Mavrič Klenovšek, and A. Gaberščik. 2020. Complex undisturbed riparian zones are resistant to colonisation by invasive alien plant species. Water 12: 345.

Živanović-Miljković, J., T. Crnčević, and I. Marić. 2012. Land use planning for sustainable development of peri-urban zones. Spatium 28: 15-22.

Publisher's Note Springer Nature remains neutral with regard to jurisdictional claims in published maps and institutional affiliations.

\section{AUTHOR BIOGRAPHIES}

Nicola S. du Plessis is a previous student in the Conservation Ecology and Entomology Department, Stellenbosch University. Her research interests include biological invasions, ecosystem-based adaptation, restoration ecology and ecosystem service science.

Address: Department of Conservation Ecology and Entomology, Stellenbosch University, Private Bag X1, Matieland 7602, South Africa.

e-mail: nickidup@gmail.com
Alanna J. Rebelo is a Post-Doctoral researcher at the Department of Conservation Ecology \& Entomology at Stellenbosch University, South Africa. Her research interests include ecohydrology, wetland ecology, applied remote-sensing, ecosystem service science, landscape ecology and restoration ecology.

Address: Department of Conservation Ecology and Entomology, Stellenbosch University, Private Bag X1, Matieland 7602, South Africa.

e-mail: arebelo@sun.ac.za

David M. Richardson is a Distinguished Professor at Stellenbosch University and is Director of the DSI-NRF Centre of Excellence for Invasion Biology. $\mathrm{He}$ is a plant ecologist who works mainly on the ecology and management of invasive woody plants, on the role of mutualisms in biological invasions, and on conceptual issues that underpin the field of invasion science.

Address: Centre for Invasion Biology, Stellenbosch University, Private Bag X1, Matieland 7602, South Africa.

Address: Department of Botany and Zoology, Stellenbosch University, Private Bag X1, Matieland 7602, South Africa.

e-mail: rich@sun.ac.za

Karen J. Esler $(\bowtie)$ is a Distinguished Professor in the Department of Conservation Ecology \& Entomology at Stellenbosch University, South Africa. Her interdisciplinary research interests include understanding how drivers of change (e.g. over-exploitation, habitat fragmentation and alien invasion) influence population and community structure and processes in Mediterranean-type ecosystems, arid ecosystems and riparian vegetation. The applied aspect of this work has been to develop and translate best-practice advice for management, restoration and conservation.

Address: Department of Conservation Ecology and Entomology, Stellenbosch University, Private Bag X1, Matieland 7602, South Africa.

Address: Centre for Invasion Biology, Stellenbosch University, Private Bag X1, Matieland 7602, South Africa.

e-mail: kje@sun.ac.za 